\title{
ARTICLES
}

\section{Maximum number of Griffon Vultures ever recorded on active migration in a single day at the Strait of Gibraltar.}

\author{
Juan Ramírez \\ C/- Héroe de Sostoa Nº 69, 29002 Málaga, Spain \\ queperita@hotmail.com
}

http://dx.doi.org/10.4314/vulnew.v73i1.1

\begin{abstract}
The Strait of Gibraltar is the most important bottleneck for Griffon Vulture (Gyps fulvus) migration in the Palaeartic but its monitoring has been irregular during the last four decades. The breeding population in Spain and the number of vultures recorded migrating across the Strait have both increased, as has the knowledge about their migratory routes, favourable migratory weather conditions and this species' overall phenology. Despite this, the Griffon Vulture is still one of the least monitored major species in the Strait of Gibraltar. On assessing the weather forecasts during the autumn of 2015 it was predicted that the 28th October was a possible vulture migration "DDay". The resulting total was an impressive 2,362 Griffon Vultures arriving on the Moroccan side of the Strait of Gibraltar; the biggest number ever recorded in a single day for this species.
\end{abstract}

\section{Introduction}

The Griffon Vulture Gyps fulvus is distributed from the Iberian Peninsula and north-west Africa to south-west Asia and northern India
(Del Hoyo et al. 1994). Its major population is concentrated in Spain with a minimum of 24,609 breeding pairs, suggesting a population of 
around 80,000 individuals (Del Moral 2009).

Formerly it was considered as a resident species, but some studies indicated that (predominantly young) individuals from northern Spain leave their colonies and cross the Strait of Gibraltar to reach the Sahelian belt, south of the Sahara (Elósegui \& Elósegui 1977, Bernis 1983, Alonso 1984, Griesinger 1998). The first migrating vultures crossing the Strait start as early as August and birds continue crossing into December. The peak period of autumn passage is from late October to early November, with the 30th of October marked as the median date for the migration of Griffon Vultures across the Strait of Gibraltar (Onrubia 2015). This is when the largest flocks congregate on the European side, sometimes waiting weeks for the optimal conditions for the flight across the shortest route to Africa. This sea crossing depends more on wind direction rather than wind force, with NW winds being the most favourable (Griesinger 1998). Griffon Vulture passage across the Strait is also characterised by the concentration of a high number of vultures crossing over just in few days among the autumn migration season (Bernis 1983, Griesinger 1998).
Autumn counts of migrating Griffon Vultures have recorded increasing numbers over the last 40 years, since the early 70 s when Pineaud and Giraud (1974) observed fewer than 600 individuals. Subsequently, 734 were counted in 1976 (Bernis 1980); an estimated 1,000 birds were migrating in the 80 s (Finlayson 1992), and at least 2,160 (mostly juveniles) in the early 90s (Griesinger 1994). The MIGRES Program recorded 2,649 in 1999 (SEO/BirdLife 1999) and 4,816 in 2000 (SEO/BirdLife 2000). The latest estimates of Griffon Vultures migrating across the Strait are around 8,000 birds during autumn migration (Onrubia 2015), with a maximum of 1,807 birds on 29th October 2008 (Ramírez 2009). This increase is more than likely due to the significant increase of the Griffon Vulture population over the last four decades (Martí 2003). These figures make the Strait of Gibraltar the most important migration spot for vultures in the Palaeartic and the most important one for the Griffon Vulture in the world.

There has been no systematic field work conducted on Griffon Vulture migration in the Strait of Gibraltar carried out since 2013, and there are no published data available from Griffon Vulture migration in 
the Strait of Gibraltar during the last decade, although there is some information related to movements of Rüppell's Vultures in the area (Ramírez et al. 2011). This is largely due to the tendency of this species to migrate mostly during October and November, whereas the majority of migrating species of raptors and storks occurs between July and early October, when most of the monitoring effort takes place. Furthermore, migration fieldwork from the African side of the Strait of Gibraltar has been scarcely carried out and no bibliography is available apart from isolated records (incluir go-south.org) since the 70s (Pineaud $\&$ Giraud 1974).

The aims of this work are to address the importance of single mass movements or "D-Days" for the crossing of the Strait of Gibraltar and also to contribute to the only available data of Griffon vulture migration in the Strait of Gibraltar since 2011 (Migres 2011), describing the highest number of migrating vultures ever recorded crossing the Strait in a single day.

\section{Methods and Results}

The weather in the Strait during the weeks prior to the 28th of October 2015 included heavy precipitation and strong easterly winds, which inhibited any southward migration. This was reinforced by no observations of migrating Griffon vultures made by local birders during those weeks (Rachid El Khamlichi pers. comm.). The number of vultures remaining on the European side of the Strait kept increasing, with regular groups of vultures arriving from the north, a situation that has been described previously by Finlayson (1992). Given the adverse weather conditions and considering the weather forecast (WindGURU) the author moved to the northernmost point of the Moroccan shore of the Strait on the evening of 27th October in anticipation of a large movement on 28th. The morning of the 28th October 2015 witnessed optimal migration weather - a light west wind (Beaufort Scale force 2), a partially cloudy sky and excellent visibility, which perfectly matched with the previously described requirements for a crossing of the Strait.

From three consecutive locations, Cape Cires $\quad\left(35^{\circ} 54^{\prime} 20.07^{\prime} \mathrm{N}\right.$ 5²8'53.81'W), Al Marsa Mirador (35 53'18.38”N 5 27'37.52 W) and the Jbel Moussa Southern slope (35 $\left.53^{\prime} 6.95^{\prime \prime} \mathrm{N} 5^{\circ} 25^{\prime} 49.92^{\prime \prime} \mathrm{W}\right)$, the author (from 08:00 hrs a.m. to 16:00 hrs UTC) recorded 2,362 vultures 
arriving in off the sea onto the most birds arriving between Moroccan shore between 09:30 hrs Alhamiar and Almarsa capes, all in and 15:30 hrs (UTC). The section of the Tanger province (Figure 1). This the Moroccan shoreline involved in stretch of coastline involves the the arrival is $7.52 \mathrm{~km}$ wide, from northernmost tip of Morocco and the Cape Cires at the westernmost point shortest sea crossing between Africa and Cape Leona at the easternmost, and Europe.

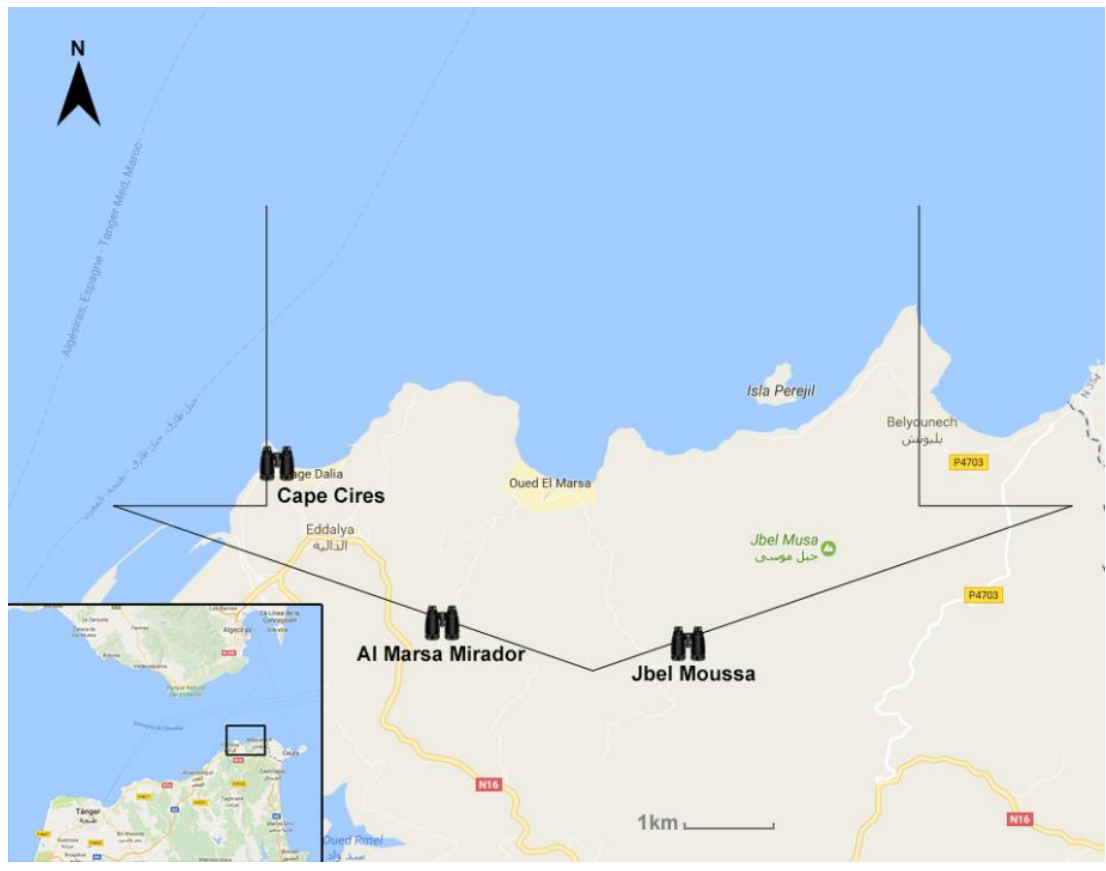

Figure 1: Map of the study area in North Morocco, located on the southern shore of the Strait of Gibraltar. The three lookouts are marked and the coast section that comprises the entrance of the vultures is limited with an arrow.

\section{Discussion}

The actual number of vultures was movements between the three probably higher because, during the observation locations, recording was 
interrupted and some vultures would have been able to pass through unrecorded. Regardless, the recorded umber exceeds the previous maximum day record of vultures across the Strait by more than five hundreds birds.

Another observer also recorded (http://www.magornitho.org/) this arrival but from 09:00 hrs to 15:00 hrs, from a fixed location at Jbel Moussa, with an estimate of 3,500 vultures by the end of the day. This number, however, is more than likely an over-estimate, given that some counts were made of inland kettles, instead of rows of gliding vultures heading in off the sea, which provides a more accurate count. Therefore 2,362 should be considered the most accurate minimum count.

This record is the largest number of Griffon Vultures ever recorded crossing the Strait of Gibraltar in a single day, and probably the world. The implication is that more than a quarter of all the Griffon Vultures that have ever been observed, yearly, across the Strait during the last averaged autumns did so in just one day.
The location where the largest counts of migrating vultures were made, and thus probably the most suitable for monitoring the crossing, was Al Marsa Mirador, which comprised birds coming from the direction of Cires and Almarsa capes. Furthermore, some of the vultures passing by Punta Leona fly over the Jbel Moussa Mountain and soar over the slopes to the east of Almarsa cape before finally gliding southwards, and can be counted this way also from Al Marsa Mirador. The temporal distribution of vultures arriving on the Moroccan side (see Figure 2) shows that most crossing were completed in the afternoon, which was more widespread and later in the day than Bildstein (2009) described.

Surprisingly, no vultures were recorded crossing the Strait the next day (29th October 2005), characterised by a light easterly wind (Beaufort Scale force 1-2) accompanied by sunshine and excellent visibility. However a flock of several hundred vultures was detected along the European shore from a distance of at least $21 \mathrm{~km}$. 


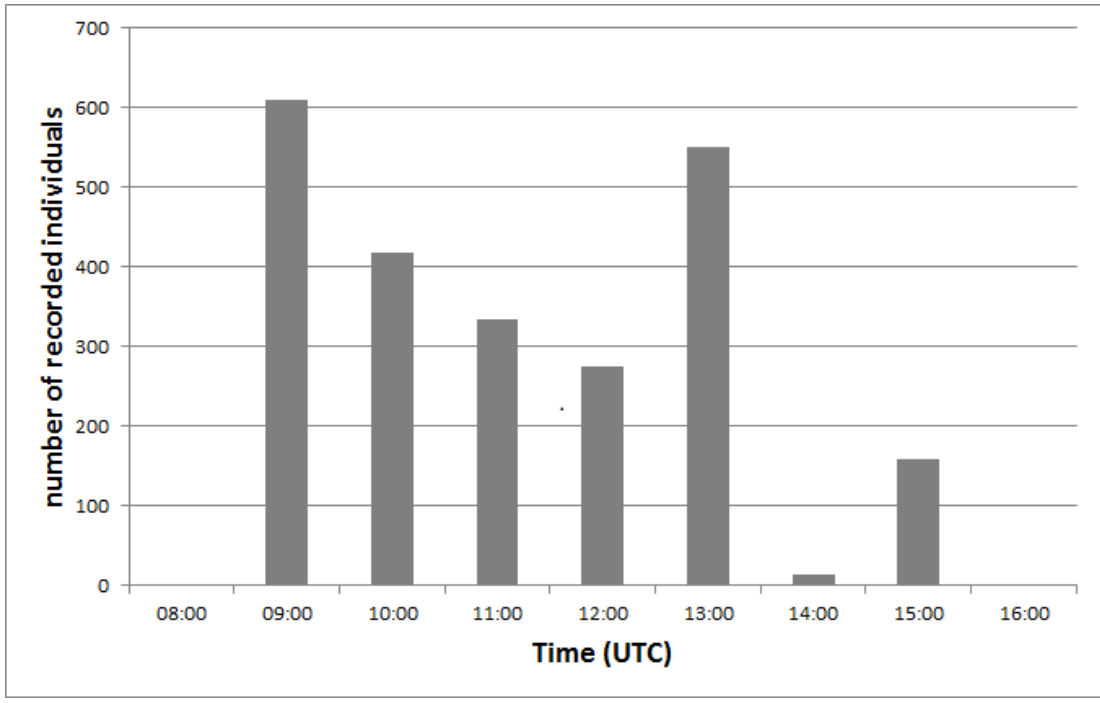

Figure 2: Temporal distribution of vultures arriving on the African shore after crossing the Straits of Gibraltar between $08 \mathrm{~h} 00$ and $16 \mathrm{~h} 00$ (UTC).

\section{Conclusion}

With the availability of accurate weather forecasting and knowledge of weather over previous weeks in the Strait, it was presumed that the 28th October was the most likely date for recording a massive Griffon Vulture arrival on the Moroccan side of the Strait of Gibraltar. The day turned out to be the best Griffon Vulture migration day ever recorded in the Strait of Gibraltar and so the best for any vultures in the Palearctic. The predictability of these massive events or "D-Days" relies on two key factors, the very specific weather requirements of Griffon Vultures for crossing the Strait of Gibraltar and the phenology of the autumn migration for this species.

In the absence of an ideal specific and systematic monitoring that the Griffon Vulture requires, these predictable and massive "D-Day" counts can be carried out relatively simply and with affordable resources. Such counts can provide useful data about the timing, spatial occurrence and quantity of Griffon Vulture autumn migrations.

Other factors that need to be taken into consideration are the important advantages of counting 
soaring migrants on the arrival shore of the Strait of Gibraltar instead of the departure coast. This is because the reduced height of the arriving birds on the Moroccan coast makes bird detection easier. More importantly, big flocks of Griffon Vultures sometimes make several abortive attempts at crossing the sea, starting high over the European shore and often gaining several kilometres over the sea before coming back to the original coast. This typical behaviour has been described as 'hesitating' by the main authors that studied Griffon Vulture migration in the Strait (Bernis 1983, Griesinger 1994, Bildstein 2009). This behavioural feature makes monitoring difficult and counting imprecise from the European shore because birds that hesitate or abort attempted sea crossings can return to the Spanish shore and be recounted once they reintegrate into another flock about to depart. This is likely to be the main source of error mentioned by Bernis (1980, 1983) when gathering field data for this species. Duplicate counts, however, are minimised (if not nullified) when those flocks of vultures reach the African shore. They then head rapidly southwards and inland upon seeing an expanse of terra firma.

\section{Acknowledgements}

Special thanks to Antonio Román Muñoz, Jack Ashton-Booth, Martina Scacco and another reviewer for improving the draft and Rachid El Khamlichi for his work in the Moroccan side of the Strait of Gibraltar. Martin Bustos kindly provided the figures. Carlos Torralvo and Javier Elorriaga brilliantly run the WhatsApp group "Aves del Estrecho"; thank you two and all the users who make it so useful. Finally, Mariví Santana helped improve readability of earlier drafts.

\section{References}

Alonso, J.A. (1984) Sur les quartiers d'hiver des vautours fauves migrateurs. Alauda 52: 308-309.

Bernis F. (1980) La Migración de las Aves en el Estrecho de Gibraltar. Vol. I Aves Planeadoras. Madrid.

Bernis F. (1983) Migration of the Common Griffon Vulture in the Western 
Palearctic. In. Wilbur S.J. and Jackson J.A. (eds) Vulture Biology and Management. University of California Press, Berkeley and Los Angeles.

Bildstein K.L., Bechard M.J., Farmer C., Newcomb L. (2009) Narrow sea crossings present major obstacles to migrating Griffon vultures Gyps fulvus. Ibis 151: 382-381.

Del Hoyo J., Elliot A. \& Sargatal J. (1994) Handbook of the Birds of the World.Vol. II New World Vultures to Guinea fowl. Lynx Edicions, Barcelona.

Del Moral J.C. (2009) El buitre leonado en España. Población reproductora en 2008 y método de censo. SEO/BirdLife. Madrid.

Elósegui J., Elósegui R. (1977) Desplazamientos de Buitres comunes (Gyps fulvus) pirenaicos. Munibe 29: 97-104.

Finlayson C. 1992. Birds of the Strait of Gibraltar. T. \& A.D. Poyser, London.

Griesinger J. (1994) Autumn Migration of Griffon Vultures (Gyps fulvus) in Spain. In Muntaner, J. \& Mayol, J. (Eds.) (1996) Biología y Conservación de las Rapaces Mediterráneos (1994) Monografías, nº 4 SEO, Madrid.

Griesinger J. (1998) Juvenile dispersión and migration among Griffon vulture Gyps fulvus in Spain. In Chancellor, R.D.; Meyburg, B-U \& Ferrero, J.J. (Eds.) (1998) Holarctic Birds of Prey. ADENEX-WWGBP. 